\title{
Banking system, Institutional quality, and Economic growth: Panel data analysis on a sample of countries in the MENA region
}

\author{
Lamia Jamel ${ }^{\mathrm{a}, \mathrm{b}, *}$ \\ ${ }^{a}$ Department of Economics and Finance, College of Business Administration, Taibah University, Medinah, 41411, Saudi Arabia \\ ${ }^{b}$ Department of Economic Sciences, Faculty of Economic Sciences and Management of Sousse, Sousse University, Sousse, 4022, Tunisia
}

\begin{abstract}
The nexus among financial development and economic growth has long remained a subject matter of considerable debate in the financial and economic literature. This article examines the relationships between financial development, institutions, and economic growth. This indicates that the marginal effect of financial development on economic growth depends on the quality of institutions. To do so, we employ a panel data of 14 MENA countries during the period of study from 2008 to 2019 . For the econometric methodology, we use fixed and random effects models. To choose between fixed effects and random effects, we employ the Hausman test. Based on the empirical findings, we demonstrate that financial development has a positive effect on economic growth. Furthermore, we have observed that institutional quality seems to be a necessary complement to financial development. Consequently, it is important to implement policies leading to the deepening of financial systems, through a including a solid institutional framework. Thus, by promoting such development and better institutional quality, economic growth will thus be accelerated.
\end{abstract}

Keywords: Banking system, economic growth, financial development, Panel data analysis.

\section{Introduction}

The link between financial development and economic growth has received much attention in recent decades. Indeed, it has been suggested that countries that are relatively more financially developed are better able to avoid or withstand currency crises (Federici and Carioli, 2009).

Therefore, strengthening financial development in many developing countries can have important positive consequences for the many organizations and individuals in those countries who are affected by economic downturns. In terms of institutional quality and financial sector performance, North African countries are making significant progress in improving the institutional environment and financial deepening.

Differences in institutional quality and financial development can have a significant impact on economic growth. In more applied studies, institutions appear crucial to support markets and increase competition, for the definition and application of property rights and contracts, for the dissemination of information on market transactions, and therefore for the reduction uncertainty in trade; in short, for the efficient distribution of resources.

A general review of the literature has highlighted the importance of institutions on economic growth (Acemoglu and Johnson, 2005). Recently, the empirical literature on economic growth has explored the impact of financial development on economic growth conditioned by the quality of a country's institutions. Most research has examined the interaction between institutions and financial development on economic growth since the two factors can be either complementary or substitute. So far, the evidence for this interaction is mixed and inconclusive.

\footnotetext{
* Corresponding author.

E-mail address: lajamel@yahoo.fr (Lamia Jamel)
} 
While Anwar and Cooray (2012) argue that improving institutions and financial development are both necessary conditions for stimulating economic growth, Ahlin and Pang (2008) confirm that both factors are substitutes for determine economic growth.

This paper examines the effect of the interaction between development and financial institutions on economic growth in the context of North African and Middle Eastern countries. Financial development contributes to economic growth, which in turn generates additional income for governments and people in the region through fiscal policies and job creation.

In addition, the quality of institutions and better governance tend to amplify the positive effects of financial development on economic growth in the region. It is therefore important that governments in this region continue to invest in social infrastructure while improving the quality of their institutions and governance, as this will enable them to avoid the kind of turmoil we have witnessed recently.

The main objective of this article is to examine the role of institutions in mediating the effect of financial development on economic growth on a panel of 14 countries in the MENA region, over a period from 2008 to 2019. Our Dynamic panel regression analyzes show that financial development has a positive and significant effect on the economic growth of countries in the region. This study also highlights the positive complementarities between financial development and institutions. This implies that, to benefit from financial development in terms of economic growth, the financial systems of MENA countries must be part of a solid institutional framework.

The rest of the document is structured as follows. Section 2 presents a review of the literature. Section 3 describes the data used and the methodology adopted. Section 4 presents the empirical results. Finally, section 5 concludes.

\section{Literature review}

In the early theory of economic growth, it is argued that economic development is a process of innovations in which the interactions of innovations in the financial and real sectors constitute a driving force for dynamic economic growth.

It is argued that exogenous technological progress determines the long-term growth rate, while financial intermediaries are not explicitly modeled to affect the long-term growth rate.

However, today there is a growing body of theoretical and empirical literature on how financial intermediation mobilizes savings, allocates resources, diversifies risks, and contributes to economic growth (Jbili et al., 1997). The new growth theory argues that financial intermediaries and markets arise endogenously in response to market incompleteness and therefore contribute to long-term growth.

Levine (1997) and Khan and Senhadji (2000) review a large body of empirical research that deals with the relationship between the financial sector and long-term growth. Levine (1997) identifies five functions that the financial system can perform to improve information and transaction frictions and contribute to long-term growth.

Khan and Senhadji (2000) also summarize the empirical evidence from the country case studies. They conclude that economic growth generally leads to financial deepening, suggesting that there is a strong reverse causality between financial development and growth.

On the other hand, Yu et al. (2012) found that the stock market has not been a predictor of economic growth in regions of Eastern Europe, Central Asia, Latin America, and the Caribbean where the link between finance and growth is very low. Therefore, they recommended making different political efforts in these geographic regions and income groups.

In addition, several recent studies have empirically tested the impact of the financial sector and financial repression policies on the rate of economic growth. Since financial development is not easily measurable, papers that attempt to study the link between financial deepening and growth have chosen several indirect measures and then have come up with various outcomes (Al-Awad and Harb, 2005; Khan and Senhadji, 2000).

In recent decades, institutions, as a fundamental cause of economic growth, have received increasing attention from 
researchers and policy makers. Evidence suggests that a country's institutional framework is crucial in determining its economic growth (Acemoglu \& Johnson, 2005; Chauffour, 2011; Nawaz, 2015).

By way of illustration, Acemoglu and Johnson (2005) found that institutions that affect all sectors of the economy have an important direct effect on financial development. They have shown that property rights and contracting institutions are important determinants of financial development. Chauffour (2011) argues that institutions, measured by economic freedom and civil and political liberties, determine why some countries achieve and maintain better economic growth.

Baier et al. (2012) note that in the period immediately following a crisis, there is usually a decrease in economic freedom that stems from increased regulation, which portends slower economic growth in the future. Hafer (2013) show that countries with a higher level of initial economic freedom show on average higher levels of financial intermediary development in subsequent years. Nawaz (2015) also established that institutions play an important role in determining the economic growth of developed economies relative to developing economies.

Law et al. (2013) find that the link between financial development and growth depends on the quality level of institutions, thus supporting the idea that better financing is important to promote economic growth. Barajas et al. (2013) note that the beneficial effect of financial deepening on economic growth varies across countries; low-income countries benefit less because their regulatory and supervisory systems are less developed.

For the region of study, Ben Naceur et al. (2014) show that the quality of institutions, in particular the rule of law, promotes financial development by signaling confidence in the quality of the legal system in support of economic activity. Gazdar and Cherif (2015) indicate that finance is more likely to support economic growth in MENA countries with healthy institutional environments. More recently, Law et al. (2017) argued that the marginal impact of financial development on economic growth depends on the quality of institutions. Our study relates to the objective of this last study - to examine the effect of institutional quality on the link between finance and growth and, also, to adopt the empirical model with interaction variables.

Sghaier (2018) finds, using dynamic panel analysis (GMM), that financial development has a positive effect on economic growth. The author also asserts that institutions seem to work in addition to financial development and that the effect of this is more pronounced in the presence of the institutional quality variable. Accordingly, the author recommends that particular emphasis be placed on the implementation of policies that result in the deepening of financial systems. Thus, by promoting the development of a country's financial system, economic growth will be accelerated.

\section{Data and methodology}

\subsection{Data}

This article examines a sample of 14 MENA countries. The choice of countries selected for this study is mainly dictated by the availability of reliable data over the sample period. The panel covers the period 2008-2019. The dependent variable is economic growth, measured as real GDP per capita at 2010 prices in US dollars. The main variable of interest (financial development) and the other control variables are obtained from the World Bank database, 2019).

In this study, we use the credit provided by the banking sector to GDP to measure financial development. This indicator measures the degree of intermediation achieved by the banking system, including credit to the public and private sectors.

Calderon and Liu (2003) suggest that this indicator has an advantage in that it only considers credit to the private sector and isolates credit given to the private sector, as opposed to credit given to governments, government agencies and businesses. public. In addition, it excludes credits issued by the central bank.

Our basic model includes explanatory variables common to most growth regressions found in the literature: 
1) Initial GDP per capita (log): log of real GDP per capita. A negative coefficient is expected, indicating the existence of conditional convergence between countries; This variable was delayed by 5 years to capture the impact of the explanatory variables.

2) Investment (\% of GDP) defined as the ratio of gross fixed capital formation to GDP. A positive coefficient is expected, because it has been shown that larger investment shares are positively linked to economic growth (Mankiw et al., 1992).

3) Trade openness measured by the ratio of total imports to exports and GDP. Assuming that openness to international trade is beneficial for economic growth, a positive coefficient is expected.

To take into account, the effects of macroeconomic stability on economic growth, two additional variables will be added to the model:

1) The rate of inflation measured as the annual percentage change in the consumer price index. A negative coefficient is expected, as high inflation has been found to have a negative effect on economic growth (Elder, 2004)

2) Public expenditure defined as the ratio of central government expenditure to GDP. An excessively large government is expected to crowd out private sector resources and harm economic growth. Thus, a negative coefficient is expected.

The extended model will also include the following institutional variable:

- The Index of Economic Freedom is constructed by the Fraser Institute and is a measure of the degree of economic freedom in terms of five broad areas: (1) size of government, taxes and businesses; (2) legal structure and security of property rights; (3) access to healthy currency; (4) the freedom to trade internationally and (5) the regulation of credit, labour, and business.

\subsection{Methodology}

The objective of our empirical analysis is to examine whether economic freedom (EF) plays an important role in influencing the effects of financial development on the economic growth of MENA countries. For this purpose, we use the following specification:

$$
y_{i,}=\alpha y_{i,-1}+\beta_{1} F D_{i, t}+\beta_{2} E F_{i, t}+\beta_{3} X_{i, t}+\delta_{i}+\varepsilon_{i, t}
$$

\section{Results and discussions}

In table (1), the results of the first model (1) clearly indicate that the estimated coefficient of the financial development variable is statistically significant at the $10 \%$ level, which suggests that the development of the banking sector plays a positive role in stimulating economic growth in the countries of the region studied. Thus, this result corroborates the results by Law et al. (2013).

On the other hand, the coefficient of economic freedom is also positive and statistically significant at conventional levels, which implies that economic growth is stronger when the index of economic freedom is high, as it thus makes investments more productive. This therefore ties in with the work carried out by De Haan et al. (2006) and AzmanSaini et al. (2010) who assert that the index of economic freedom is essential for economic growth. Note that the coefficients of the fundamental variables considered in the equation enter the regression equation with the correct sign and are significant at the $10 \%$ level or more, except for the inflation variable.

After carrying out the Hausman test, the results show that it is significant (0.0058), we will favor the fixed effects. Hausman's specification test is a general test that can be applied to many specification problems in econometrics. But its most widespread application is that of specification tests for individual panel effects. It is used to discriminate between fixed and random effects. It is an orthogonality test between the explanatory variables and the error term of 
the random effects model.

Investment measured by gross fixed capital formation and trade openness have positive and statistically significant coefficients, indicating that greater openness of investment and trade promotes economic growth. Regarding macroeconomic stability, inflation and government size show the expected signs, but only the latter is statistically significant.

Table 1. Estimation results

\begin{tabular}{ccc}
\hline $\begin{array}{c}\text { Dependent Variable: } \\
\text { lnGDPpc }\end{array}$ & Fixed effects (1) & Random effects (2) \\
\hline Inflation & $-0.026(0.215)$ & $-0.004(0.820)$ \\
Invest & $0.067 * * *(0.000)$ & $0.044^{* * *}(0.002)$ \\
Openness & $0.027 * * *(0.000)$ & $0.015 * * *(0.001)$ \\
GovExp & $0.096^{* *}(0.013)$ & $0.096^{* * *}(0.001)$ \\
DevFin & $0.007 *(0.090)$ & $0.004 *(0.060)$ \\
EcoFree & $0.062^{* * *(0.012)}$ & $0.050^{* * *}(0.015)$ \\
Constant & $-0.155(0.924)$ & $9.570^{* * *}(0.000)$ \\
$R^{2}$ & 0.402 & 0.284 \\
No. of observation & 146 & 146 \\
\hline Notes: Standard error in parentheses. *, **,*** significance at the $10 \%, 5 \%$ and $1 \%$ level, respectively.
\end{tabular}

\section{Conclusion}

The link between financial development and economic growth has long remained a subject of significant debate in the literature. Therefore, this paper aims to re-examine the role of institutions in mediating the positive relationship between financial development and economic growth in the MENA region. This implies that the marginal impact of financial development on economic growth depends on the quality of institutions.

To test the hypothesis, this work uses the estimator of fixed effects and random effects on the data of a sample of countries in the MENA region, over a period going from 2008 to 2019. From the empirical analysis, we drew three important conclusions. The first, the coefficient measuring the impact of the banking system on economic growth is positive and significant, which indicates that financial development affects economic growth positively. The second, it turns out that the index of economic freedom which measures the quality of institutions is an important factor of economic growth for the sample of countries considered. Finally, the effect of development on economic growth depends on the level of the latter in host countries. This means that a better institutional environment allows an economy to explore the benefits of financial sector reforms in promoting economic growth.

In this sense, countries should propose measures that strengthen institutional reforms to improve the functioning of financial systems and economic growth. We believe that a healthy institution is a key priority for governments to enable their financial systems to perform essential functions to improve the efficiency of intermediation and push production towards its potential. However, building more effective institutions will be a long and arduous process. In some countries, it may be politically difficult for governments to undertake a series of reforms in the short term, however in the long term they can bring significant economic benefits.

To achieve the desired benefits of financial development and facilitate increased investment and growth, political efforts should be directed to deepening the financial sector and building financial systems conducive to growth. By way of illustration, policies should focus on restricting government interference in the financial system, investing in human resources, strengthening the legal environment, and improving competition by reducing public spending. Regulatory reforms that strengthen creditors' rights, contract enforcement and accounting practices are expected to stimulate the development of banks and securities markets.

Different policies should be made to achieve the objective of economic growth considering the stability of financial development distinct according to the sample countries and according to their income groups. However, it is true that unlike time series analysis, we get a positive relationship between financial development and growth based on our estimates. It would be interesting to introduce other institutional components and characteristics, in particular the type of financial system and policies, to explain and further substantiate the differences and specificities between the countries studied. 


\section{Acknowledgements}

The author would to think the Editor in Chief and the anonymous reviewers for their important suggestions and remarks to improve the quality of the paper.

\section{References}

Acemoglu, D., \& Johnson, S., (2005). Unbundling Institutions, Journal of Political Economy, 113(5), 949-995. https://doi.org/10.1086/432166

Ahlin, C., \& Pang, J. (2008). Are financial development and corruption control substitutes in promoting growth?, Journal of Development Economics, 86(2), 414-433. https://doi.org/10.1016/j.jdeveco.2007.07.002

AlAwad, M., \& Harb, N. (2005). Financial Development and Economic Growth in the Middle East, Applied Financial Economics, 15(15), 1041-1051. https://doi.org/10.1080/09603100500120639

Anwar, S., \& Cooray, A., (2012). Financial development, political rights, civil liberties and economic growth: Evidence from South Asia, Economic Modelling, 29(3), 974-981. https://doi.org/10.1016/j.econmod.2012.02.009

Baier, S.L., Clance, M., \& Dwyer, G.P. (2012). Banking crises and economic freedom, In: Gwartney, J., Lawson, R.A., Hall, J. (Eds.), Economic Freedom of the World: 2013 Annual Report. The Fraser Institute, Vancouver, 201-217. https://www.centroeinaudi.it/images/stories/Chapter_4.pdf

Barajas, A., Chami, R., \& Yousefi, R. (2013). The finance and growth nexus reexamined: do all countries benefit equally?, IMF Working Paper, No. 130. https://www.imf.org/external/pubs/ft/wp/2013/wp13130.pdf

Ben Naceur, S., Cherif, M., \& Khandil, M. (2014). What drives the development of the MENA financial sector?", Borsa Istanbul Review, 14(4), 212-223. https://doi.org/10.1016/j.bir.2014.09.002

Calderon, C., \& Liu, L. (2003). The direction of causality between financial development and economic growth, Journal of Development Economics, 72(1), 321-334. https://doi.org/10.1016/S0304-3878(03)00079-8

Chauffour, J.P. (2011). On the relevance of freedom and entitlement in development: new empirical evidence (19752007), The World Bank, Policy Research Working Paper No. 5660, 1-37. https://openknowledge.worldbank.org/bitstream/handle/10986/3423/WPS5660.pdf?sequence=1\&isAllowed=y

Federici, D., \& Carioli, F. (2009). Financial development and growth: an empirical analysis, Economic Modelling, 26(2), 285-294. https://doi.org/10.1016/j.econmod.2008.07.006

Gazdar, K., \& Cherif, M. (2015), Institutions and the finance-growth nexus: Empirical evidence from MENA countries, Borsa Istanbul Review, 15(3), 137-160. https://doi.org/10.1016/j.bir.2015.06.001

Hafer, R.W., (2013). Economic freedom and financial development: international evidence, Cato Journal, 33(1), 111$126 . \quad$ https://www.cato.org/sites/cato.org/files/serials/files/cato-journal/2013/1/cj33n16.pdf?queryID $=\mathrm{c} 4 \mathrm{c} 5 \mathrm{a} 75 \mathrm{~d} 81 \mathrm{f} 18 \mathrm{f} 113 \mathrm{be} 4 \mathrm{e} 130 \mathrm{~b} 648 \mathrm{f} 383$

Jbili, A., Enders, K., \& Treichel, V. (1997). Financial Reforms in Algeria, Morocco, and Tunisia: A Preliminary Assessment, IMF Working Paper, No. 97/81. https://www.imf.org/external/pubs/ft/wp/wp9781.pdf

Khan, M., \& Senhadji, A. (2000). Financial Development and Economic Growth: An Overview, IMF Working Paper, No. 209. http://dx.doi.org/10.5089/9781451874747.001

Law, S.H., Kutan, M.A., \& Naseem, N.A.M. (2017). The role of institutions in finance curse: Evidence from international data, Journal of Comparative Economics, 46(1), 1-18. https://doi.org/10.1016/j.jce.2017.04.001

Levine, R. (1997). Financial Development and Economic Growth: Views and Agenda, Journal of Economic Literature, 35(2), 688-726. https://doi.org/10.1596/1813-9450-1678 
Mankiw, N.G., Romer, D., \& Weil, D. (1992). A contribution to the empirics of economic growth, Quarterly Journal of Economics, 107, 407-437. https://eml.berkeley.edu/ dromer/papers/MRW_QJE1992.pdf

Nawaz, S. (2015). Growth effects of institutions: a disaggregated analysis, Economic Modelling, 45, 118-126. https://doi.org/10.1016/j.econmod.2014.11.017

Sghaier, I.M. (2018). Financial Development, Institutions and Economic Growth in North African Countries, The Romanian Economic Journal, $\quad$ XXI(69), 53-72. http://www.rejournal.eu/sites/rejournal.versatech.ro/files/articole/2018-10-10/3530/5sghaier.pdf

Yu, J.S., Hassan, M.K., \& Sanchez, B. (2012). A Reexamination of Financial Development, Stock Markets Development and Economic Growth, Applied Economics, 44(7), 3479-89. https://doi.org/10.1080/00036846.2011.577019 